\title{
PLAYING ACTIVE VIDEO GAMES WHILE IN A TENNIS TRAINING PROCESS: A NEW TRAINING TOOL OR A HANDICAP FOR CHILDREN?
}

\author{
Luka ŠLOSAR ${ }^{2}$, Matej PLEVNIK ${ }^{1}$, Uroš MARUŠIČ ${ }^{3,4}$ \\ ${ }^{1}$ University of Primorska, Faculty of Health Sciences, Department of Kinesiology and \\ Physiotherapy, Izola, Slovenia \\ ${ }^{2}$ OŠ Vincenzo e Diego de Castro, Piran, Slovenia \\ ${ }^{3}$ Institute for Kinesiology Research, Science and Research Centre Koper, Slovenia \\ ${ }^{4}$ Department of Health Sciences, Alma Mater Europaea - ECM, Maribor, Slovenia \\ Corresponding Author: \\ Uroš MARUŠIČ \\ Institute for Kinesiology Research, Science and Research Centre Koper, \\ Garibaldijeva 1, 6000 Koper, Slovenia \\ Phone: +38656637700 \\ E-mail: uros.marusic@zrs-kp.si and umarusic@outlook.com \\ ORCID ID: https://orcid.org/0000-0002-7420-2137
}

\section{ABSTRACT}

Aim: The purpose of this pilot study was to quantify the effect of a continued active video games $(A V G)$ playing on the tennis forehand and backhand technique development.

Methods: Altogether 24 tennis players (7 - 9 year olds) were randomly divided in two different groups, both involved in a 12-week tennis training program (twice a week for an hour). The participants in the experimental group received an additional twice a week (20-minute) AVG Virtua Tennis 4 game intervention at the end of each regular tennis training hour, while the participants in the control group received no additional intervention. Pre- and post-AVG intervention, the Tennis Rating Score for Children scale (TRSC) was applied to detect tennis training-related changes that occur in each specific stroke.

Results: Our results at the post-test show that participants in the experimental group did not significantly improved in one element (TRSC12; $p=0,317$ ) in the forehand stroke and two (TRSC10; $p=0,157$ and TRSC12 $p=0,157)$ in the backhand. The control group significantly improved in all the fifteen evaluated elements in both the forehand and backhand stroke. The experimental group had a higher effect size in 
all the kinetic chain section in both the forehand and backhand stroke compared to the control. The same happens for the TRSC7 (point of contact-height).

Conclusion: Prolonged AVG playing seems to improve visual attentions skills (perception of a moving object) in young tennis players, giving them the opportunity to be able to prepare themselves for the oncoming ball sooner as compared to their control counterparts. From the other perspective, AVG were shown to negatively affect correct players positioning, especially at the beginning and at the end of a stroke.

Keywords: exergames, tennis technique, visual attention skills.

\section{IGRANJE AKTIVNIH VIDEO IGER V PROCESU UČENJA TENISA OTROK: NOVO VADBENO ORODJE ALI OVIRA?}

\section{IZVLE $\check{C} E K$}

Cilj: Namen pilotske študije je bil preučiti vpliv dolgotrajnega igranja aktivnih video iger (AVG) na proces usvojitve tehnike teniških udarcev bekend in forhend.

Metode: $V$ študiji je sodelovalo 24 teniških igralcev starih 7 do 9 let, ki so bili naključno razdeljeni $v$ dve skupini. Obe skupini sta bili vključeni $v$ 12-tedenski teniški program usposabljanja (dvakrat na teden po eno uro). V prvi, t. i. eksperimentalni skupini, so igralci poleg rednega procesa treninga, bili deležni 20 minutnega igranja AVG Virtua Tennis 4 neposredno po treningu. Kontrolna skupina se je udeleževala le rednega procesa treninga. Za oceno izvedbe tehnike udarcev smo uporabili lestvico teniškega napredka (TRSC).

Rezultati: Po 12-tedenski intervenciji eksperimentalna skupina ni pomembno napredovala $v$ enem elementu (TRSC12; $p=0,317)$ pri forhend udarcu in dveh (TRSC10; $p=0,157$ in TRSC12; $p=0,157)$ pri bekend. Kontrolna skupina je pomembno napredovala $v$ vseh petnajstih elementih tako pri forhend kot bekend udarcu. Eksperimentalna skupina je imela višjo vrednost učinka pri vseh elementih kinetične verige tako pri bekend kot forhend udarcu $v$ primerjavi s kontrolno skupino. Enako velja za element TRSC7 (višina točke udarca).

Zaključek: Dolgotrajno igranje AVG naj bi izboljšalo vidno zaznavne sposobnosti mladih teniških igralcev in s tem omogočilo hitrejšo postavitev na udarec. Po drugi strani negativno vpliva na pravilno tehnično postavitev in zamah pri forhend in bekend udarcih. Rezultati predstavljajo koristne informacije tako za starše kot trenerje o vplivu AVG na teniški razvoj mladih igralcev.

Ključne besede: aktivne video igre, tehnika udarcev, vidno prostorske sposobnosti. 


\section{INTRODUCTION}

Active video games (hereinafter AVG) represent a new video games generation that introduced controllers and motion sensing input devices, for which a whole body physical interaction is required while playing (Mears \& Hansen, 2009). Compared to the traditional sedentary video games, the new virtual reality experience allowed its users to see, hear and feel the environment as being part of it. AVG are able to track full-body movements in three dimensions, can measure reaction times, accelerations and detect the speed of a player's movement (Staiano \& Calvert, 2011). While playing, the users need to simulate the basic movements and features that represent the key elements and specificities of each sport, hence they are able to express the most authentic replication of a real sport experience.

The most popular AVG devices are the commercially available Xbox, Wii, and PlayStation consoles. According to Fulton et al. (2012), $40 \%$ of adolescents play video games at least once a week, $83 \%$ of Americans aged between 8 and 18 have at least one AVG console at home while $56 \%$ have two or more (Rideout, Foehr \& Roberts, 2010).

The fast growing interest in AVG made them a significant research area. Studies were mainly focused on the contribution they can offer as a weapon against sedentary lifestyle and a way to promote wellness. Review articles and meta-analysis for observational studies (Peng, Lin \& Crouse, 2011; Peng, Crouse \& Lin, 2013) proved that playing AVG compared to inactivity, increase heart rate, oxygen consumption (VO2) and energy expenditure. Even more recent studies (Newel, 2013; Mills et al. 2013) demonstrate that a critical threshold of 3 METs (Metabolic Equivalents), representing moderate activities ( 3.5 to $7 \mathrm{kcal} / \mathrm{min}$ ), can be achieved while playing AVG. According to the above-mentioned studies, playing AVG increases physiological body responses. The unexplained field remains the influence of those games on the development of motor abilities and fundamental movement skills (Barnett, Hinkley, Okely, Hesketh \& Salmon, 2012), which provide the basis for a more successful performance of sport-specific movement skills (Lubans, Morgan, Cliff, Barnett \& Okely, 2010). Furthermore, few studies have been conducted on children using AVG and none on tennis.

Since 2007, the Physical Activity Council (2016) reports a $6 \%$ increase in tennis players, which is the highest increment among all analyzed sports. Currently, nearly 4000 young professional tennis players ( $<19$ years old) are listed in the International Tennis Federation (ITF). Due to the fast growing number of professional tennis players across the world and the subsequent increasing competitiveness, the intensity and volume of training programs have been led to a higher level in early ages, intended to reach superior results (Reid, Crespo \& Santilli, 2009). In accordance with the International Tennis Federation Coaches' Education Program (Crespo \& Reid, 2009), 6 to 12-year-old children represent the Introduction / Foundation stage in a tennis world class players' development guidelines, with the main goal of fully mastering the technique of basic strokes (forehand, backhand, serve). All the distinct phases of a player development are inextricably linked together (Saviano, 2001) and without successfully acquired fundamentals (technique of basic strokes), the increasing intensity 
and volume of training sessions, which are enhanced in the second phase, may lead to injuries.

As AVG are mainly used among adolescents, when the development of motor skills is in full swing, determining their positive and negative effects may offer the prospect of a possible application using them in favor of improving physical performance by their influence on motor efficiency and learning. On the other side, repetitive performance of irregular movement patterns may destroy the correct execution of the strokes that were previously learned during the training sessions. Therefore, the aim of our study was to evaluate the impact of a continued AVG playing on the tennis technique development during the training process in 7- to 9-year-old children.

\section{METHODS}

\section{Participants}

This research was conducted on 24 tennis players ( 7 females, 17 males, average age $7.95 \pm 0.92$ years, range $7-9$ year olds) recruited from the local tennis club (Tennis Club Portorož, Slovenia, EU). After a detailed presentation of the study, its purpose, and study design to the participants and parents, we obtained a written parental consent for each child. The inclusion criterion was no more than two years of regular participation in a tennis training process; players with injuries or long-term body impairments that prevented them from performing shots as they are usually instructed were excluded. The study was approved by the Republic of Slovenia National Medical Ethics Committee, number 0120-631/2017/2.

\section{Study Design}

The participants were randomly allocated into experimental (tennis training + AVG; 11 participants; female: 3; male: 7) and control (only tennis training; 13 participants; female: 1; male: 12) group. Both groups attended a 12-week tennis training program (twice a week for an hour), where the experimental group had an additional AVG intervention which lasted 20 min per session and was administred after each "physical" tennis training. For AVG, the Virtua Tennis 4 game on Xbox 360 console was chosen. We used the kinect device that allowed the participants to play using merely the movements of their body.

The children were involved in a novice tennis training program where each training session lasted for one hour, with an emphasis on tennis strokes technique execution and motor skills development (agility, balance, coordination, power, reaction time and speed). The AVG intervention program was implemented to be able to gradually increase the difficulty of the game. The game itself provides different levels of difficulty for "human player vs. computer option", as well as an option to play with "multiple 
Luka ŠLOSAR, Matej PLEVNIK, Uros MARUŠIČ: PLAYING ACTIVE VIDEO GAMES WHILE IN A TENNIS TRAINING PROCESS ..., 75-88

human players". For our intervention, both options were chosen depending on the number of children involved and mixed troughout the whole interventional period. The participants with an absence percentage up to 15 (more than 3 times) were eliminated from the investigation.

\section{Outcome Measures}

Our participants are novice tennis players, therefore, as stated in the introduction, their main goal is to fully master the technique of main strokes. For assessing the progress made in the game of tennis, we used the TRSC that evaluates the improvement made in technique of both the forehand and backhand stroke. We decided not to assess the serve stroke, as the children up to 9 years of age who have not yet developed enough power for such a complex movement play the stroke only in its most basic version. The scale divides each stroke in fifteen different elements that need to be evaluated to reach the final score. We followed the protocol which had previously been validated in Šlosar, Šimunic, Pišot \& Marusic, (2018). The TRSC is divided into fifteen different elements (Figure 1) that need to be evaluated to reach the final score, i.e. the current technical knowledge in a specific stroke. The elements correspond to different postitions end motions starting from the stroke preparation to a follow-through and the kinetic chain, that all evaluate the coordinated activation of all body segments involved (for details see Šlosar, Šimunic, Pišot \& Marusic, 2018). The evaluation needs to be performed while reviewing the execution previously recorded on a video tape with the possibility of viewing it in slow motion and pausing the recording at the desired player position. Video clips were made using high quality video facilities on mobile phones and free computer applications for editing. All the evaluated elements were rated on 5-point grading Likert scale. 


\begin{tabular}{|c|c|c|c|c|c|}
\hline 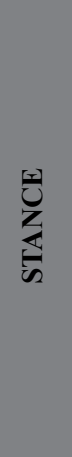 & 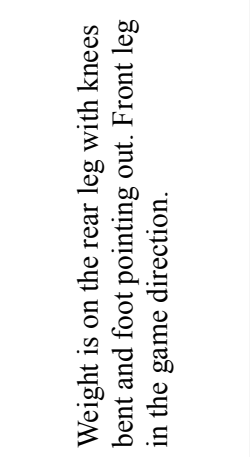 & 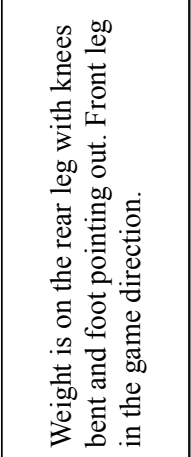 & 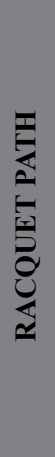 & 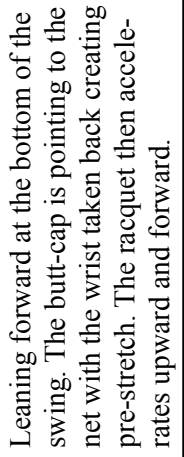 & 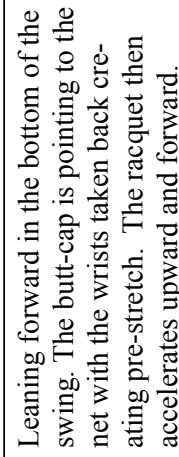 \\
\hline 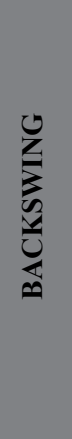 & 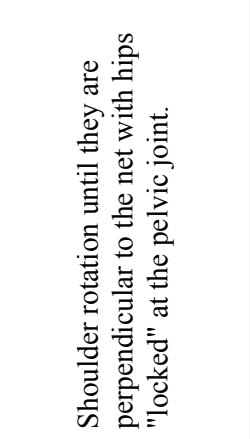 & 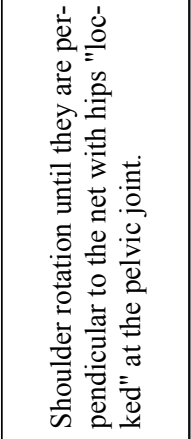 & $\begin{array}{l}Z \\
0 \\
= \\
0 \\
\vdots \\
0 \\
\vdots \\
\vdots \\
\vdots \\
\vdots\end{array}$ & 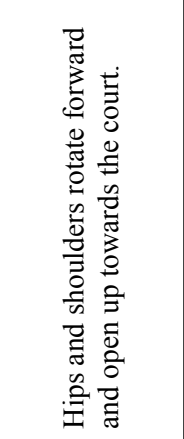 & 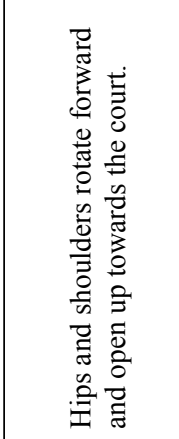 \\
\hline 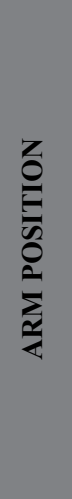 & 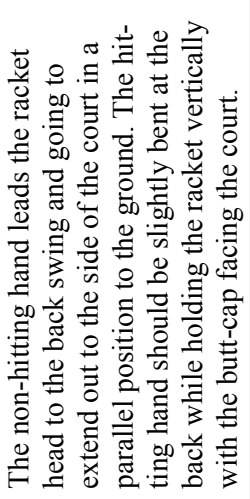 & 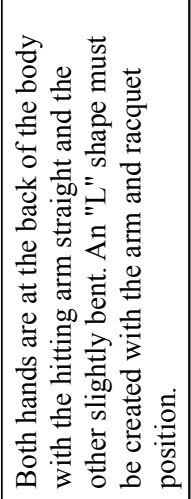 & 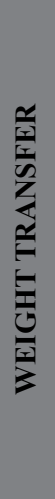 & 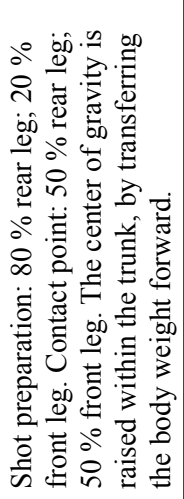 & 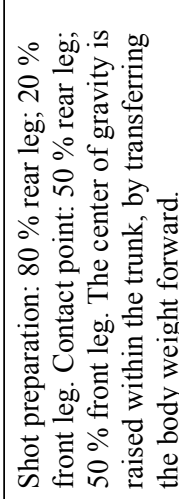 \\
\hline 前 & 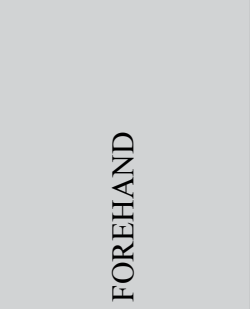 & 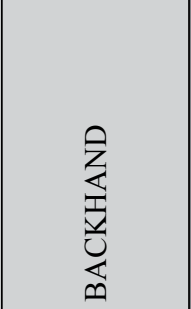 & 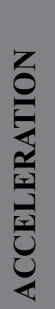 & 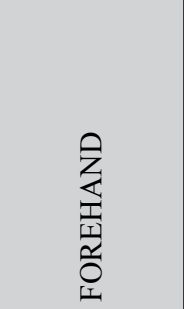 & 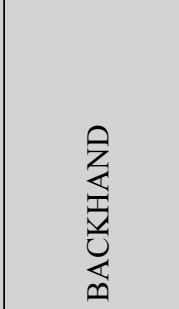 \\
\hline
\end{tabular}




\begin{tabular}{|c|c|c|c|c|c|c|c|c|}
\hline 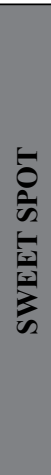 & 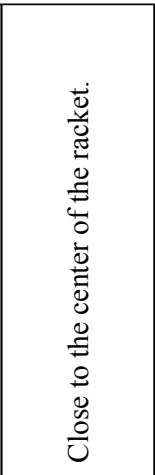 & 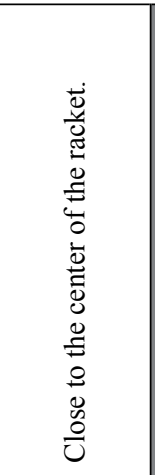 & 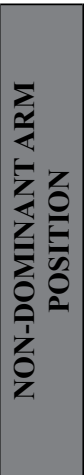 & 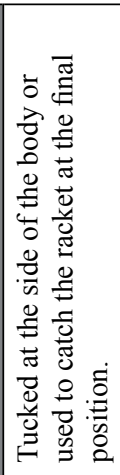 & 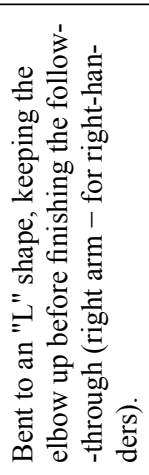 & $\sum^{U}$ & 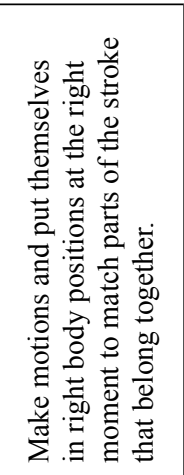 & 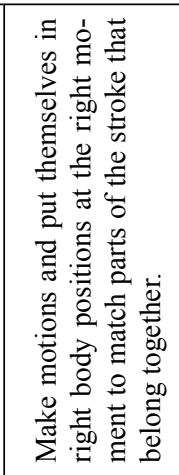 \\
\hline 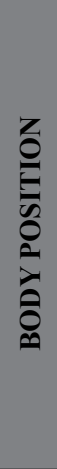 & 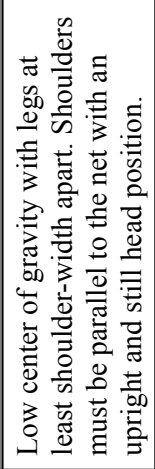 & 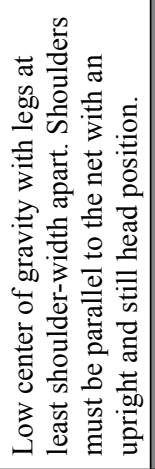 & $\begin{array}{l}z \\
0 \\
\vdots \\
0 \\
0 \\
\vdots \\
\vdots \\
\vdots \\
0 \\
0 \\
\simeq \\
\simeq\end{array}$ & 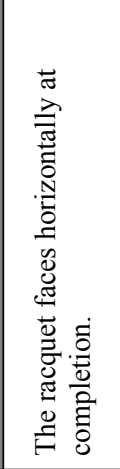 & 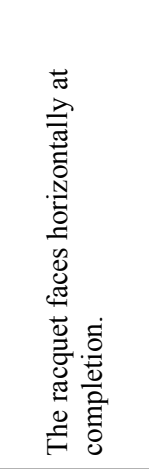 & 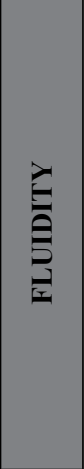 & 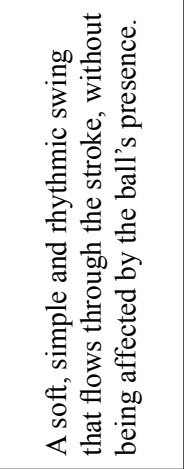 & 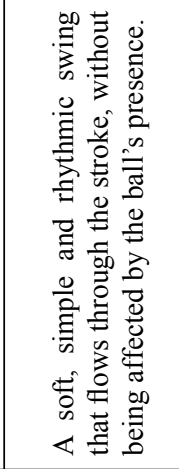 \\
\hline & 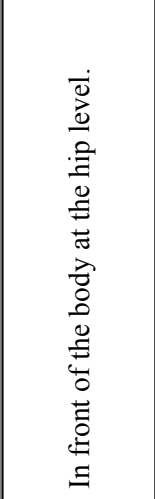 & 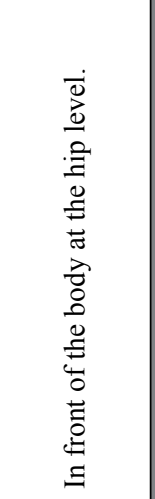 & $\begin{array}{l}z \\
0 \\
\vdots \\
0 \\
0 \\
\vdots \\
z \\
z=1\end{array}$ & 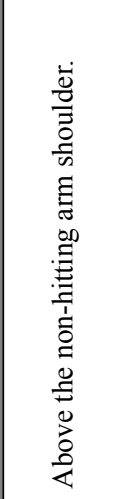 & 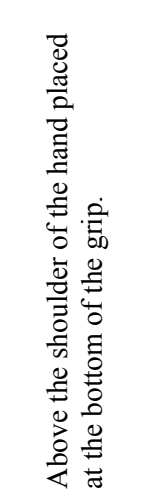 & 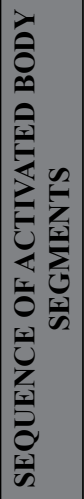 & 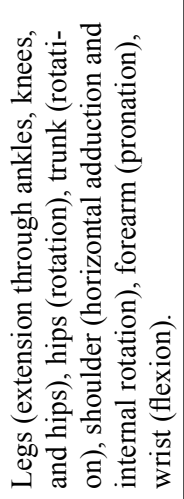 & 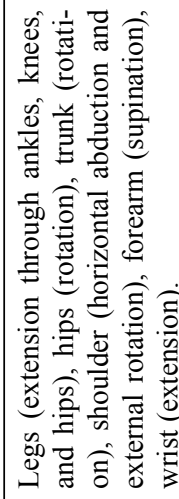 \\
\hline 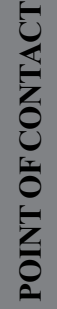 & 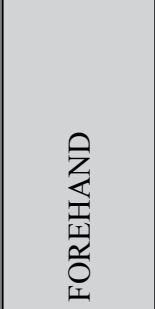 & 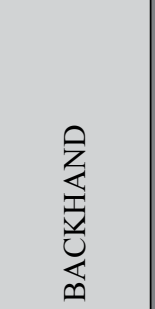 & 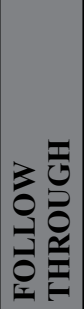 & 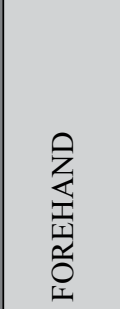 & 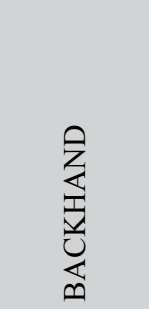 & 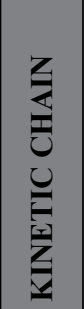 & 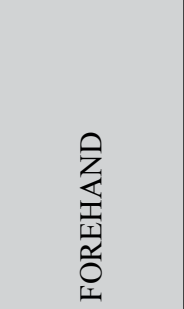 & 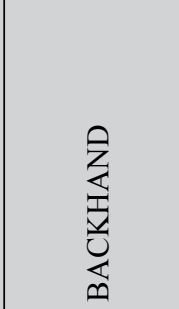 \\
\hline
\end{tabular}




\section{Procedure}

The evaluation was performed by the participants' tennis coach. All the participants were evaluated on a forehand and backhand stroke on Day 1 and Day 84 (pre- and post-intervention). To better understand the influence of a continued AVG playing on a tennis technique, only the results corresponding to fifteen evaluated elements were considered, while the final TRSC score is primarly used to make the data analysis more comprehensible, especially for the players' parents.

\section{Statistical Analysis}

The distribution of each evaluated element (TRSC scale) was examined on a normal quantile (Q-Q) plot as well as a histogram to determine whether the data were well approximated by a normal (Gaussian) distribution. Non-normally distributed data were summarized with means and standard deviations. The results between the control and experimental group at the pre-test were compared using the Mann Whitney U-test. Differences between pre- and post-test for the control and experimental group were evaluated with a Wilcoxon test. The intervention effect size was estimated and interpreted by Cohen (1988) as follows: $>0.1$ small; $>0.3$ medium; $>0.5$ large effect.

A p value $<0.05$ was considered statistically significant.

\section{RESULTS}

All the participants from the initially included 24 were taken into statistical analyses. The data from all fifteen elements of the TRSC were non-normally distributed ( $\mathrm{p}<$ 0.05). Mann Whitney test showed no significant differences for both the forehand and backhand stroke between the experimental and control group at the pre-test. Table 1 shows the baseline characteristics of the children included.

Table 2. Characteristics of included children.

\begin{tabular}{|l|c|c|c|c|}
\hline & \multicolumn{2}{|c|}{ Experimental group } & \multicolumn{2}{c|}{ Control group } \\
\hline & M & SD & M & SD \\
\hline $\begin{array}{l}\text { Experience } \\
\text { (months) }\end{array}$ & 15 & 0.72 & 17 & 0.71 \\
\hline Age & 7.43 & 0.82 & 8.38 & 0.96 \\
\hline Height & 130.73 & 9.43 & 141.00 & 9.16 \\
\hline Weight & 27.18 & 4.6 & 35.85 & 6.28 \\
\hline
\end{tabular}




\section{Forehand}

A Wilcoxon test revealed a significant improvement at the post-test for all the fifteen evaluated elements in the control group. A moderate effect size was shown in TRSC7 (0.42) and TRSC9 (0.46). In all the other elements, the effect was large and greater than 0.52 . At the post-test, the experimental group did not significantly improve in TRSC12 $(p=0.317)$. The same element revealed a low effect size (0.21). A moderate effect size was shown in TRSC1 (0.43) and TRSC10 (0.48). In all the other elements, the effect size was large and greater than 0.52 .

Table 3. Wilcoxon test between the pre and post-test for the experimental and control group for the forehand stroke.

\begin{tabular}{|c|c|c|c|c|c|c|}
\hline \multicolumn{5}{|c|}{ Control group } & \multicolumn{3}{c|}{ Experimental group } \\
\hline TRSC & Pre-test & Post-test & P(ES) & Pre-test & Post-test & P (ES) \\
\hline $\mathbf{1}$ & $2.69 \pm 0.48$ & $3.54 \pm 0.66$ & $0,001(0,64)$ & $2.09 \pm 0.70$ & $2.27 \pm 0.47$ & $0,046(0,43)$ \\
\hline $\mathbf{2}$ & $2.54 \pm 0.97$ & $2.85 \pm 0.55$ & $0,001(0,66)$ & $2.27 \pm 0.79$ & $2.82 \pm 0.40$ & $0,011(0,54)$ \\
\hline $\mathbf{3}$ & $2.31 \pm 0.86$ & $2.92 \pm 1.25$ & $<0,001(0,69)$ & $2.00 \pm 0.63$ & $2.45 \pm 1.03$ & $0,002(0,67)$ \\
\hline $\mathbf{4}$ & $2.38 \pm 0.77$ & $2.38 \pm 0.77$ & $<0,001(0,71)$ & $2.09 \pm 0.70$ & $2.09 \pm 0.70$ & $0,003(0,64)$ \\
\hline $\mathbf{5}$ & $2.23 \pm 0.83$ & $2.77 \pm 0.56$ & $0,002(0,60)$ & $2.18 \pm 0.75$ & $2.73 \pm 0.47$ & $0,003(0,64)$ \\
\hline $\mathbf{6}$ & $2.00 \pm 0.70$ & $2.62 \pm 0.65$ & $0,004(0,57)$ & $1.82 \pm 0.40$ & $2.27 \pm 0.78$ & $0,002(0,65)$ \\
\hline $\mathbf{7}$ & $2.54 \pm 0.78$ & $2.85 \pm 0.69$ & $0,034(0,42)$ & $2.27 \pm 0.79$ & $3.45 \pm 0.52$ & $0,002(0,64)$ \\
\hline $\mathbf{8}$ & $2.31 \pm 0.75$ & $2.31 \pm 0.75$ & $0,005(0,55)$ & $2.09 \pm 0.70$ & $2.09 \pm 0.70$ & $0,005(0,60)$ \\
\hline $\mathbf{9}$ & $3.00 \pm 1.08$ & $3.31 \pm 0.75$ & $0,020(0,46)$ & $2.45 \pm 1.03$ & $3.00 \pm 0.63$ & $0,011(0,54)$ \\
\hline $\mathbf{1 0}$ & $2.85 \pm 0.99$ & $3.08 \pm 0.86$ & $0,004(0,57)$ & $2.82 \pm 0.98$ & $3.18 \pm 0.75$ & $0,025(0,48)$ \\
\hline $\mathbf{1 1}$ & $2.38 \pm 0.77$ & $3.08 \pm 0.64$ & $0,001(0,64)$ & $1.91 \pm 0.83$ & $2.45 \pm 0.69$ & $0,014(0,52)$ \\
\hline $\mathbf{1 2}$ & $2.85 \pm 0.55$ & $3.38 \pm 0.77$ & $0,005(0,55)$ & $2.82 \pm 0.40$ & $2.82 \pm 0.40$ & $0,317(0,21) *$ \\
\hline $\mathbf{1 3}$ & $2.54 \pm 0.78$ & $2.62 \pm 0.65$ & $0,008(0,52)$ & $2.27 \pm 0.79$ & $2.45 \pm 0.52$ & $0,003(0,63)$ \\
\hline $\mathbf{1 4}$ & $2.23 \pm 0.73$ & $2.69 \pm 0.48$ & $0,001(0,65)$ & $2.00 \pm 0.63$ & $3.00 \pm 0.63$ & $0,002(0,67)$ \\
\hline $\mathbf{1 5}$ & $2.00 \pm 0.58$ & $2.31 \pm 0.75$ & $0,003(0,59)$ & $1.82 \pm 0.40$ & $3.00 \pm 0.48$ & $0,002(0,67)$ \\
\hline
\end{tabular}

Notes: ES $=$ effect size; $* \mathrm{p}>0,05$ 


\section{Backhand}

A Wilcoxon test revealed a significant improvement at the post-test for all the fifteen evaluated elements in the control group. A moderate effect size was shown in TRSC7 (0.44). In all the other elements, the effect was large and greater than 0.53 . At the post-test the experimental group did not significantly improve in TRSC10 (0.157) and TRSC12 $(\mathrm{p}=0.157)$. The same elements revealed a moderate effect size $(0.30)$, as it is for TRSC1 (0.48), TRSC8 (0.30) and TRSC9 (0.43). In all the other elements, the effect size was large and greater than 0.58 .

Table 4. Wilcoxon test between the pre and post-test for the experimental and control group for the backhand stroke.

\begin{tabular}{|c|c|c|c|c|c|c|}
\hline & \multicolumn{5}{|c}{ Control group } & \multicolumn{3}{c|}{ Experimental group } \\
\hline TRSC & Pre-test & Post-test & P(ES) & Pre-test & Post-test & P (ES) \\
\hline $\mathbf{1}$ & $2.38 \pm 0.77$ & $3.08 \pm 0.64$ & $0,001(0,65)$ & $2.18 \pm 0.60$ & $2.36 \pm 0.67$ & $0,025(0,48)$ \\
\hline $\mathbf{2}$ & $2.00 \pm 0.82$ & $2.31 \pm 0.63$ & $0,001(0,63)$ & $2.18 \pm 0.75$ & $2.45 \pm 0.52$ & $0,005(0,60)$ \\
\hline $\mathbf{3}$ & $1.85 \pm 0.69$ & $2.62 \pm 0.87$ & $0,001(0,64)$ & $1.45 \pm 0.52$ & $2.27 \pm 0.79$ & $0,001(0,68)$ \\
\hline $\mathbf{4}$ & $2.23 \pm 0.83$ & $2.31 \pm 0.75$ & $0,001(0,64)$ & $2.00 \pm 0.63$ & $2.00 \pm 0.63$ & $0,007(0,58)$ \\
\hline $\mathbf{5}$ & $1.85 \pm 0.55$ & $2.62 \pm 0.51$ & $0,001(0,63)$ & $1.91 \pm 0.54$ & $2.91 \pm 0.54$ & $0,002(0,67)$ \\
\hline $\mathbf{6}$ & $1.85 \pm 0.69$ & $2.08 \pm 0.64$ & $0,001(0,65)$ & $2.00 \pm 0.63$ & $2.00 \pm 0.63$ & $0,008(0,64)$ \\
\hline $\mathbf{7}$ & $2.46 \pm 0.78$ & $2.62 \pm 0.51$ & $0,025(0,44)$ & $2.36 \pm 0.67$ & $3.45 \pm 0.52$ & $0,002(0,58)$ \\
\hline $\mathbf{8}$ & $2.00 \pm 0.82$ & $2.15 \pm 0.89$ & $0,001(0,63)$ & $2.00 \pm 0.63$ & $2.00 \pm 0.63$ & $0,003(0,30)$ \\
\hline $\mathbf{9}$ & $2.54 \pm 0.78$ & $3.08 \pm 0.64$ & $0,003(0,58)$ & $2.27 \pm 0.78$ & $2.82 \pm 0.40$ & $0,007(0,43)$ \\
\hline $\mathbf{1 0}$ & $2.54 \pm 0.78$ & $2.77 \pm 0.44$ & $0,001(0,67)$ & $2.64 \pm 0.80$ & $2.82 \pm 0.40$ & $0,157(0,30 *$ \\
\hline $\mathbf{1 1}$ & $2.31 \pm 0.75$ & $2.92 \pm 1.04$ & $0,001(0,64)$ & $1.73 \pm 0.78$ & $1.82 \pm 0.75$ & $0,046(0,63)$ \\
\hline $\mathbf{1 2}$ & $2.54 \pm 0.78$ & $2.92 \pm 0.49$ & $0,001(0,63)$ & $2.64 \pm 0.80$ & $2.64 \pm 0.81$ & $0,157(0,30 *$ \\
\hline $\mathbf{1 3}$ & $2.31 \pm 0.75$ & $2.46 \pm 0.52$ & $0,007(0,53)$ & $2.18 \pm 0.75$ & $2.36 \pm 0.50$ & $0,003(0,63)$ \\
\hline $\mathbf{1 4}$ & $1.77 \pm 0.44$ & $2.38 \pm 0.76$ & $<0,001$ & $1.82 \pm 0.40$ & $2.82 \pm 0.40$ & $0,001(0,71)$ \\
\hline $\mathbf{1 5}$ & $1.92 \pm 0.49$ & $2.15 \pm 0.68$ & $0,002(0,62)$ & $1.82 \pm 0.40$ & $3.00 \pm 0.48$ & $0,001(0,68)$ \\
\hline
\end{tabular}

Notes: ES $=$ effect size; $* \mathrm{p}>0,05$ 


\section{DISCUSSION}

The aim of the present pilot study was to evaluate the impact of a prolonged AVG playing on the tennis technique of two main strokes while being in a tennis training process. Our results show similar intervention effects among both the forehand and backhand stroke. The evaluated TRSC12element has not been improved by the experimental group in both the forehand and backhand stroke. The same stands for the TRSC10 element only in the backhand stroke. As part of the follow-through sections, prolonged AVG playing seems to negatively affect a proper player positioning at the end of the stroke. A poorer attention at the correct tennis positions is also noted comparing the effect size among groups at the TRSC1, which stands for the arm position at the shot preparation. In both the backhand and forehand stroke, the stroke is large in the control group and moderate in the experimental. The results may find explanation upon the model of control the user had over the actions of the avatar in AVG, which are more prominent on simple reaction times and timing of the hand swing. If the hand does not swing at the right time, the avatar would fail to shoot the ball, which is not considered to be a successful stroke in this model.

The whole kinetic chain section (the sequence of activated body segments; fluidity; timing), is the only one among both strokes where the experimental group had a higher effect size. The TRSC13 element (the sequence of activated body segments) had a large effect size in the experimental group compared to the moderate in the control. The same happens with the TRSC7 element (point of contact - height) in both strokes. The results may suggest that AVG might increase a player's reaction time and attention towards the ball arriving from the other side of the court. The results seem to confirm the ones concluded by Green and Bavelier $(2003 ; 2006)$ which demonstrate higher visual attention skills in video game players compared to non-players. Improved visual attention skills represent the ability to track objects moving at a higher speed, track multiple items at the same time, eliminate irrelevant visible information, increase focusing and concentration capabilities.

The constant technology development managed to create natural user interfaces and gesture recognition video game consoles which are able to track full-body movements in three dimensions, thus offering the opportunity to play virtual sports as being in a real environment. The results of the present study support Wiemeyer \& Kliem (2012) theories, asserting that, due to the way of playing some motor control competencies may be enhanced, such as: reaction time, balance, endurance, strength and rhythmic abilities. Furthermore, Wiemeyer \& Hardy (2013) in accordance with our results, confirmed that a possible transfer of motor learning settings between the real and virtual environment may be possible while using AVG.

To our knowledge, this is the first study that evaluates the effects of prolonged AVG playing on specific sport technique execution and not performance. Several limitations are however acknowledged in the study, starting from the lack of a third group playing just AVG without any real tennis practice and the small sample size used. Furthermore, a combination of technical and precision skills (suitable for beginners) would extend 
the range of knowledge about AVG. Finally, we cannot generalize results among the entire middle age population, as they are related to participants with a specific status, like children from wealthy families, or those with high expectations of accomplishment. Although the findings of this pilot study do suggest that a possible transfer of motor learning settings between the real and virtual environment may be possible, this still needs to be addressed on larger samples.

\section{CONCLUSION}

On the basis of the above, as many AVG like the Virtua Tennis 4 require rapid movements, they may improve general visual attention skills. On the other side, they can negatively affect correct technique positioning. The results of our study suggest a specific adaptation of playing AVG while being in the tennis process. Namely, 7- to 9-year-old children who play AVG (Virtua Tennis 4) twice a week for three months (24 x AVG + tennis trainings) are more progressive in cognitive domain, while having negative adaptation from the perspective of tennis technique acquisition (the first and the last part of a stroke motion). The present study shows the effect of playing / not playing AVG in children while being in the early process of tennis training program, and better understand the impact of AVG games on players' physical skills. Finally, the results of our pilot study, the first of its kind, could serve as - a scientific evidence noting to which extent playing AVG influences the tennis technique.

\section{Acknowledgements}

We thank all the coaches who provided an insight and expertise that greatly assisted the research. We are also immensely grateful to the local tennis club (Tennis Club Portorož, Slovenia, EU) and all the players who dedicated their time for this project, since this research would not have been possible without them.

\section{REFERENCES}

Barnett, L. M., Hinkley, T., Hesketh, K., Okely, A. D. \& Salmon, J. (2012). Use of electronic games by young children and fundamental movement skills. Perceptual and Motor Skills, 114(3), 1023-1034. doi: 10.2466/10.13.PMS.114.3.1023-1034 VIEW ITEM

Cohen, J. (1988). Statistical power analysis for the behavioral sciences (2nd ed.). Hillsdale, NJ: Lawrence Earlbaum Associates.

Crespo, M., \& Reid, M. (2009). Stages of player development. ITF Education Programme, Coaching High Performance Players Course. ITF Coaching \& Sport Science Review. Retrieved from http://en.coaching.itftennis.com/media/113924/113924.pdf 
Luka ŠLOSAR, Matej PLEVNIK, Uros MARUŠIČ: PLAYING ACTIVE VIDEO GAMES WHILE IN A TENNIS TRAINING PROCESS ..., 75-88

Fulton, J. E., Song, M., Carroll, D. D. \& Lee, S. M. (2012). Active video game participation in U.S. youth, Findings from the National Youth Physical Activity and Nutrition Survey, 2010. Circulation, 125, AP260.

Green, C. S. \& Bavelier, D. (2003). Action video game modifies visual selective attention. Nature, 423, 534-537.

Green, C. S. \& Bavelier, D. (2006). Enumeration versus multiple object tracking: The case of action video game players. Cognition, 101(1), 217-245. doi: 10.1016/j.cognition.2005.10.004 VIEW ITEM

Lubans, D. R., Morgan, P. J., Cliff, D. P., Barnett, L. M. \& Okely, A. D. (2010). Fundamental movement skills in children and adolescents: review of associated health benefits. Sports Medicine, 40(12), 1019-1035. doi: 10.2165/11536850-000000000-00000 VIEW ITEM

Mears, D. \& Hansen, L. (2009). Active gaming: definitions, options and implementation. Strategies. A Journal for Physical and Sport Educators, 23(2), 1-40. doi: 10.1080/08924562.2009.10590864 VIEW ITEM

Mills, A. M., Rosenberg, M., Stratton, G., Carter, H. H., Spence, A. L., Pugh, C. J. A., Green, J. D. \& Naylor, H. L. (2013). The effect of Exergaming on vascular function in children. The Journal of Pediatrics, 163(3), 806-810. doi:10.1016/j.jpeds.2013.03.076 VIEW ITEM

Newell, D. A. (2013). A Quantitative comparison of energy expenditure between exergames and physical activity recommendations. (Honors Theses, 162). Retrieved from https:// aquila.usm.edu/cgi/viewcontent.cgi?article $=1126 \&$ context $=$ honors theses

Peng, W., Crouse, J. \& Lin, J.-H. (2013). Using active video games for physical activity promotion: A systematic review of the current state of research. Heath Education \& Behavior, 40(2), 171-192. doi: 10.1177/1090198112444956 VIEW ITEM

Peng, W., Lin, J.-H. \& Crouse, J. (2011). Is playing exergames really exercising? A metaanalysis of energy expenditure in active video games. CyberPsychology, Behaviour, and Social Networking. 14(11), 681-688. doi: 10.1089/cyber.2010.0578 VIEW ITEM

Physical Activity Council. (2016). Participation Report: The physical activity council's annual study tracking sports, fitness, and recreation participation in the US. Retrieved from http://www.physicalactivitycouncil.com/pdfs/current.pdf

Reid, M., Crespo, M., \& Santilli, L. (2009). The importance of the ITF Junior Girls' Circuit in the development of women professional tennis players. Journal of Sports Sciences, 27(13), 1443-1448. doi: 10.1080/02640410903037714 VIEW ITEM

Rideout, V. J., Foehr, U. G. \& Roberts, D. F. (2010). Generation M2: Media in the Lives of 8 to 18 year-olds. Kaiser Family Foundation. Retrieved from https://files.eric.ed.gov/ fulltext/ED527859.pdf

Saviano, N. (2001). Progressive development of a world class tennis player. High- Performance Coaching, 3(2), 3-12. Retrieved from https://s3.amazonaws.com/ustaassets/ assets/1/usta import/usta/dps/doc 437 804.pdf

Staiano, A. E. \& Calvert, S. L. (2011). Exergames for physical education courses: physical, social, and cognitive benefits. Child Development Perspectives, 5, 93-98. doi: 10.1111/j.1750-8606.2011.00162.x VIEW ITEM

Šlosar, L., Šimunič, B., Pišot, R. \& Marusic, U. (2019). Validation of a Tennis Rating Score to evaluate the technical level of children tennis players. Journal of Sports Sciences, 37(1). doi: 10.1080/02640414.2018.1483184 VIEW ITEM 
Luka ŠLOSAR, Matej PLEVNIK, Uros MARUŠIČ: PLAYING ACTIVE VIDEO GAMES WHILE IN A TENNIS TRAINING PROCESS ..., 75-88

Wiemeyer, J. \& Hardy, S. (2013). Serious Games and motor learning - concepts, evidence, technology. In K. Bredl \& W. Bösche (Eds.), Serious Games and Virtual Worlds in Education, Professional Development, and Healthcare, (pp 197-220). Heshey, PA: IGI Global.

Wiemeyer, J. \& Kliem, A. (2012). Serious games in prevention and rehabilitation - a new panacea for elderly people? European Review of Aging and Physical Activity, 9(1), 4150. doi: 10.1007/s11556-011-0093-x VIEW ITEM 